\title{
Nephrin is expressed in the pancreatic beta cells
}

\author{
T. Palmén ${ }^{1}$, H. Ahola ${ }^{1}$, J.Palgi ${ }^{2}$, P. Aaltonen ${ }^{1}$, P. Luimula ${ }^{1}$, S. Wang ${ }^{1}$, I. Jaakkola ${ }^{3}$, M.Knip ${ }^{2}$, T. Otonkoski ${ }^{2}$, \\ H.Holthöfer ${ }^{1}$ \\ ${ }^{1}$ Haartman Institute, Division of Bacteriology and Immunology, University of Helsinki, and Helsinki University Central Hospital \\ Helsinki, Finland \\ ${ }^{2}$ Haartman Institute, Transplantation Laboratory and Hospital for Children and Adolescents, University of Helsinki, Helsinki, \\ Finland \\ ${ }^{3}$ National Public Health Institute, Medicity Research Laboratory, University of Turku, Turku, Finland
}

\section{Abstract}

Aims/hypothesis. The NPHS1 gene product, nephrin, is a crucial component of the glomerular filtration barrier preventing proteinuria and previously assumed to be kidney-specific. The aim of this study was to describe the expression of nephrin mRNA and protein in human pancreas as well as identify the nephrin-expressing cell types.

Methods. RNA dot blot, reverse transcriptase-polymerase chain reaction, sequencing, immunoblotting and dual immunofluorescence were used for the characterisation of nephrin in the pancreas.

Results. Except for the kidney, the pancreas was found to be the only tissue expressing nephrin as screened with a human tissue RNA dot blot. The ex- pression was verified with reverse transcriptase-polymerase chain reaction and by sequencing nephrin from a human pancreatic complementary DNA library. Nephrin antibody in immunoblot detected a $165000 \mathrm{M}_{\mathrm{r}}$ protein in the pancreas. Dual immunofluorescence showed that nephrin was specifically localised in the beta cells of the islets of Langerhans. There was no overlap with glucagon, somatostatin, or the ductal cell marker cytokeratin 19.

Conclusion/interpretation. These data show that nephrin is a novel molecule of pancreatic beta cells. [Diabetologia (2001) 44: 1274-1280]

Keywords NPHS1 gene, nephrin, immunoglobulin superfamily, islets of Langerhans, beta cell.
The congenital nephrotic syndrome of the Finnish type (CNF, NPHS1) is an autosomal recessive disease characterised by the absence of the interpodocyte slit membranes of the kidney glomeruli, leading to severe proteinuria already in utero [1]. Untreated CNF is lethal but can be effectively cured with renal trans-

Received: 25 January 2001 and in revised form: 30 May 2001

Corresponding author Harry Holthöfer, M.D., Ph. D., Haartman Institute, Division of Bacteriology and Immunology, PB 21, 00014 University of Helsinki, Finland, e-mail: Harry.Holthofer@Helsinki.Fi

Abbreviations: CNF/NPHS1, Congenital nephrotic syndrome of the Finnish type; cDNA, complementary DNA; SDS, sodium dodecyl sulphate; PCR, polymerase chain reaction; IPTG, isopropyl D-thiogalactosidase; PBS, phosphate buffered saline; TRITC, tetramethyl rhodamine; FITC, fluorescein isothiocyanate plantation [1-2]. The causative gene mutated in CNF was recently localised to chromosome 19q13.1 and named NPHS1 [3-6].

The NPHS1 gene spans $26 \mathrm{~Kb}$ and has 29 exons yielding a mRNA including 3726 bases coding for the protein [5-6]. The gene product, nephrin, is a potential member of the immunoglobulin superfamily as suggested by the amino acid sequence [5-6]. The signal peptide is coded by exon 1 , eight immunoglobulin-like domains coded by exons $2-20$ and a fibronectin type III domain coded by exons 22-23. Exon 24 encodes a transmembrane region and exons 25-29 code for the intracellular domain [6]. The predicted $\mathrm{M}_{\mathrm{r}}$ of the 1241 amino acid nephrin is 135000 but due to $\mathrm{N}$-glycosylation, the reported $\mathrm{M}_{\mathrm{r}}$ is approximately 185000 [5, 7-9]. Rat [8] and mouse [9] nephrin show close identity with human nephrin. Apart from the full-length mRNA, the NPHS1 gene yields a distinct alternatively spliced mRNA, $\alpha$-neph- 
rin, which lacks the sequence for the transmembrane region (exon 24) [7-8]. It could therefore represent a secreted form of nephrin [7].

Nephrin has been reported to be specific for kidney glomerular podocytes [5]. By immunohistochemistry and immunoelectron microscopy nephrin has been localised to the podocyte slit membrane area between podocyte foot processes [7, 9-10] but also to clusters at the lateral and apical surface of podocytes [7]. As nephrin is mutated in CNF it strongly suggests that nephrin plays a crucial part in maintaining the integrity of the whole interpodocyte slit membrane and thus the functional filtration barrier of the kidney [10]. Downregulation of nephrin has also been reported in other proteinuric syndromes and in experimental models of glomerular diseases [11-13]. In addition, it has been proposed that nephrin is also important in outside-in signalling via the eight intracellular tyrosine residues but no details of this proposed signalling function have yet emerged [5]. Unlike the original finding limiting nephrin expression to kidney podocytes [5], transcription of the reporter gene was recently detected also in the brain and pancreas of mice with lacZ expression controlled by the NPHS1 promoter [14]. We have now studied the pancreatic expression of nephrin both at the mRNA and protein level, and carefully localised the expression by dual immunofluorescent staining with specific antibodies.

\section{Materials and methods}

Human and animal tissues. The human pancreatic and kidney tissues were from human cadaveric donors. Isolated human pancreatic islets (containing $50-60 \%$ beta cells) and total pooled islet RNA were kindly provided by Dr. O. Korsgren (University of Uppsala, Sweden) and Dr. D. Eizirik (Free University of Brussels, Belgium). The procedures have been carried out in accordance with the principles of the Declaration of Helsinki.

Human tissue RNA dot blot. Human RNA Masterblot (Clontech Laboratories, Palo Alto, Calif., USA) including mRNA from 50 different tissues was used for the screening of nephrin mRNA expression in human tissues. The dot blot was hybridised with the human nephrin (GenBank AF035835) probe constructed from complementary DNA (cDNA) of normal human kidney cortex with polymerase chain reaction (PCR) using a sense primer 5'-ccaacatcgttttcacttgg (nucleotides 2606-2625) and an anti-sense primer 5'-gggaaggccatatcctcat (nucleotides 3515-3497). The product was digested with ApaI and SacI (Promega, Madison, Wis., USA) restriction enzymes. The resulting $777 \mathrm{bp}$ fragment was radioactively labelled with ${ }^{32}$ phosphorus-deoxycytidinetriphosphate using random priming (Boehringer Mannheim, Mannheim, Germany) and used as a probe. The hybridisation was done in the buffer including $5 \mathrm{xSSC}(750 \mathrm{mmol} / 1$ sodium chloride, $75 \mathrm{mmol} / \mathrm{l}$ sodium citrate, $\mathrm{pH} 7.0)$, 5xDenhardt's, $50 \mathrm{mmol} / \mathrm{l}$ sodium phosphate ( $\mathrm{pH} 6.5)$, $50 \%$ formamide, $0.1 \%$ sodium dodecyl sulphate (SDS) and $250 \mu \mathrm{g} / \mathrm{ml}$ denatured Herring sperm at $+42^{\circ} \mathrm{C}$ overnight. The blot was washed with $2 \times \mathrm{SSC}, 0.1 \% \mathrm{SDS}$ at $+42^{\circ} \mathrm{C}$ and with
$1 \mathrm{xSSC}, 0.1 \%$ SDS at $+55^{\circ} \mathrm{C}$ and analysed after 3 days of exposure with a Bio-imaging analyser (Fuji Photo Film Co, Kanakawa, Japan).

$R T-P C R$. Total RNA from isolated islets of Langerhans and from adult human pancreas, as well as from human kidney cortex was isolated with the Trizol Reagent (Life Technologies, Gibco BRL, Paisley, Scotland). The RNA samples (0.8 $\mu \mathrm{g}$ RNA from the islets, $5.5 \mu \mathrm{g}$ from the pancreas and $2.5 \mu \mathrm{g}$ from the kidney cortex) were treated with DNase I (Promega) and transcribed into cDNA using oligo $(\mathrm{dT})_{15}$ priming (Boehringer Mannheim) and Moloney-Murine Leukemia Virus reverse transcriptase (Promega) (RT + ). To confirm the RNA origin of the PCR signals, each sample was also analysed without the reverse transcriptase reaction (RT-).

Two human nephrin (GenBank AF035 835) primer pairs, a sense primer 5'-ccaacatcgttttcacttgg (nucleotides 2606-2625) and an anti-sense primer 5'-gggtggtacgacatccacata (nucleotides 2979-2959) both upstream from the sequence encoding the transmembrane sequence and the other pair with a sense primer 5'-cccatcactacccaggtct (nucleotides 3094-3113) and an anti-sense primer 5'-ctctgttgtgctgaccgtg (nucleotides 3402-3384) on either side of the transmembrane area were used for the amplification of human nephrin cDNA. As a control, the $\beta$-actin was amplified with a sense primer 5'-aaccgcgagaagatgacccagatcatgttt (nucleotides 353-382) and an antisense primer 5'-agcagccgtggccatctcttgctcgaagtc (nucleotides 674-703). The non-quantitative amplification reactions were done using AmpliTaq DNA polymerase (Perkin Elmer, Norwalk, Conn., USA) with initial denaturation of cDNA at $94{ }^{\circ} \mathrm{C}$ for $3 \mathrm{~min}$, followed by 33 amplification cycles $\left(94^{\circ} \mathrm{C} 30\right.$ $\mathrm{s}, 56^{\circ} \mathrm{C} 1 \mathrm{~min}$, and $72^{\circ} \mathrm{C} 30 \mathrm{~s}$ ), and final elongation at $72^{\circ} \mathrm{C}$ for $3 \mathrm{~min}$.

Sequencing. Human pancreatic cDNA library (Clontech) and specific primer pairs along the nephrin sequence were used in PCR. The PCR products were run in agarose gels, gelpurified (QIAquick PCR Purification kit, Quigen, Hilden, Germany) and sequenced with Amersham Thermo Sequanase II dye terminator cycle sequencing premix kit (Amersham Pharmacia Biotech, Uppsala, Sweden) and with ABI Prism 373A sequencer (Perkin Elmer, Applied Biosystems, Forster City, Calif., USA) according to the instructions of the manufacturer.

Production of nephrin antibodies. The generation and characterisation of antipeptide antibodies against intracellular amino acids 1101-1126 of nephrin (GenBank AF035 835) have been described [7]. For production of antibodies against the extracellular part of nephrin (GenBank AF125 521) the 5' sequence of extracellular nephrin (E1) (nucleotides 1-972) was amplified with primers having restriction sites for $B c l I$ (a sense primer) and for EcoRI (an anti-sense primer). The PCR product was ligated into an expression vector pGEX-2T (Amersham Pharmacia Biotech) encoding glutathione-S-transferase upstream of the cloning site digested with BamHI and EcoRI. For fusion protein production, the pGEX-2T/E1 construct was transformed into the competent E.Coli strain BL-21 (Amersham Pharmacia Biotech), grown in 2xYTAG medium (yeast extract $10 \mathrm{~g} / \mathrm{l}$, tryptone $16 \mathrm{~g} / \mathrm{l}, \mathrm{NaCl} 5 \mathrm{~g} / \mathrm{l}$, glucose $2 \%$, $100 \mu \mathrm{g} / \mathrm{ml}$ ampicillin) at room temperature. Expression was induced by IPTG (isopropyl beta-D-thiogalactosidase) (Amersham Pharmacia Biotech). After overnight incubation the cells were collected and lysed according to Frangioni and Neel [15] in STE buffer $(150 \mathrm{mmol} / \mathrm{l} \mathrm{NaCl}, 10 \mathrm{mmol} / \mathrm{l}$ Tris $\mathrm{pH} 8.0$, $1 \mathrm{mmol} / \mathrm{l}$ EDTA) including $100 \mu \mathrm{g} / \mathrm{ml}$ lysozyme, $3 \%$ sarcosyl, $5 \mathrm{mmol} / \mathrm{l}$ dithiothreitol. After centrifugation the fusion proteins were collected from supernatant using glutathione sepha- 
rose 4B (Amersham Pharmacia) in the presence of $2 \%$ Triton $\mathrm{X}-100$ and used for immunisation.

The antibodies (Glomega, Helsinki, Finland) were produced according to standard protocols. Briefly, rabbits were immunised with $250 \mu \mathrm{g}$ E1 antigen in Freund's complete adjuvant. Two booster injections ( $250 \mu \mathrm{g}$ antigen) were given at intervals of 4 weeks and serum was collected 10 days after the last injection.

Immunoblot. Human glomeruli (prepared by sieving [16]), kidney cortex, pancreas and enriched islets of Langerhans were homogenised in reducing Laemmli buffer $(62.5 \mathrm{mmol} / \mathrm{l}$ Tris$\mathrm{HCl}$ (pH 6.8), $10 \%$ glycerol, $2 \%$ SDS, $5 \%$ 2-mercaptoethanol, $0.05 \%$ bromophenol blue). The lysates were boiled for $5 \mathrm{~min}$, briefly sonicated, centrifuged $10000 \cdot \mathrm{g} 10 \mathrm{~min}$ at ${ }^{+} 4^{\circ} \mathrm{C}$. Equal aliquots from each supernatant were run through reducing $8 \%$ polyacrylamide gels in the Protean Mini-gel electrophoresis system (Bio-Rad Laboratories, Richmond, Calif., USA), and the proteins were transferred to nitrocellulose filters (Schleicher and Schuell, Dassel, Germany). After blocking overnight at $+4{ }^{\circ} \mathrm{C}$ with $3 \%$ BSA in phosphate buffered saline (PBS) $\quad(140 \mathrm{mmol} / \mathrm{l} \quad \mathrm{NaCl}, \quad 2.7 \mathrm{mmol} / \mathrm{l} \quad \mathrm{KCl}, \quad 1.5 \mathrm{mmol} / \mathrm{l}$ $\mathrm{KH}_{2} \mathrm{PO}_{4}, 8.2 \mathrm{mmol} / 1 \mathrm{Na}_{2} \mathrm{HPO}_{4}$ pH 7.4)-0.1\% Tween 20, the filters were incubated for $2 \mathrm{~h}$ with affinity purified rabbit anti nephrin intracellular antibody $(4 \mu \mathrm{g} / \mathrm{ml})$. As a control, filters were incubated with the intracellular antibody $(4 \mu \mathrm{g} / \mathrm{ml})$ adsorbed with the antigen peptide $(10 \mu \mathrm{g} / \mathrm{ml})$. The filters were washed with PBS- $0.1 \%$ Tween 20 and incubated with horseradish peroxidase conjugated swine anti-rabbit immunoglobulins (1:2500) (Dako, Glostrup, Denmark). After washes with PBS-0.1\% Tween 20, the bound antibodies were detected with the ECL blotting kit (Amersham LifeScience, Amersham International, Buckinghamshire, England).

Immunofluorescence. Frozen sections of human pancreas were fixed with $3.5 \%$ paraformaldehyde for $20 \mathrm{~min}$ and thoroughly washed with PBS. The sections were further treated with $0.1 \%$ Triton X-100 in PBS for $15 \mathrm{~min}$, washed, treated with $15 \mathrm{mmol} / \mathrm{l}$ ammonium chloride for $15 \mathrm{~min}$ and washed. Next, the sections were blocked with $10 \%$ normal goat serum for $30 \mathrm{~min}$, incubated for $1 \mathrm{~h}$ with rabbit anti nephrin (E1) antibody diluted at 1:150 $(3 \mu \mathrm{g} / 150 \mu \mathrm{l})$ or with nephrin antibody adsorbed with E1 antigen $(19 \mu \mathrm{g})$, washed, and incubated further for $1 \mathrm{~h}$ with tetramethyl rhodamine (TRITC) conjugated goat anti-rabbit IgG (Jackson Immunoresearch Laboratories, West Grove, Pa., USA) diluted at 1:150. All antibody dilutions were done in $5 \%$ normal goat serum, $0.1 \%$ Triton $\mathrm{X}-100$ in PBS. After the final wash the sections were embedded in Immu-Mount embedding medium (Shandon, Pittsburgh, Pa., USA). Microscopy was done with a Zeiss Axiophot2 microscope (Carl Zeiss Jena GmbH, Jena, Germany).

Dual immunofluorescence used to detect antigens colocalising with nephrin was carried out as described above. The dilutions of the antibodies were 1:200 for mouse anti insulin (Neo Markers, Fremont, Calif., USA), 1:100 for sheep anti glucagon (Biogenesis, Poole, UK), 1:80 for mouse anti cytokeratin 19 (Dako) and 1:150 for rabbit anti nephrin. Mouse anti somatostatin antibody (Biogenesis) was prediluted. The secondary antibodies (Jackson Immunoreseach Laboratories, West Grove, Pa., USA) used were TRITC conjugated goat anti-rabbit IgG (1:150) and fluorescein isothiocyanate (FITC) conjugated goat anti-mouse $\operatorname{IgG}+\operatorname{IgM}(1: 40)$. The combination of donkey anti-sheep $\operatorname{IgG}(1: 150)$ and donkey anti-rabbit $\mathrm{IgG}$ (1:200) was used to visualise the dual staining for glucagon and nephrin. In addition, normal donkey serum was used instead of normal goat serum.

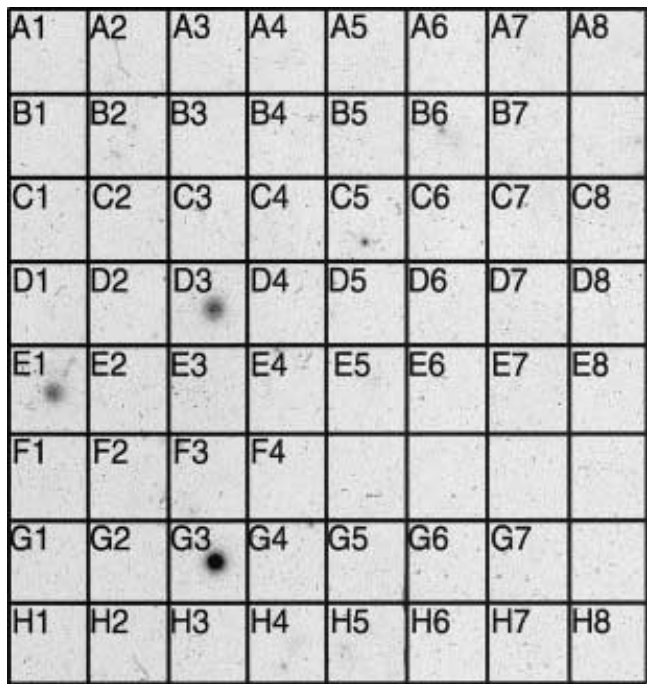

Fig. 1. Human RNA Masterblot. RNA Masterblot including mRNA from different tissues was hybridised with the human nephrin probe. Identification of the dots:

\begin{tabular}{|c|c|c|c|}
\hline A1 whole brain & C1 heart & E1 kidney & G1 fetal brain \\
\hline A2 amygdala & C2 aorta & E2 liver & G2 fetal heart \\
\hline A3 caudate & C3 sceletal & E3 small & G3 fetal \\
\hline nucleus & muscle & intestine & kidney \\
\hline A4 cerebellum & C4 colon & E4 spleen & G4 fetal liver \\
\hline A5 cerebral cortex & C5 bladder & E5 thymus & $\begin{array}{l}\text { G5 fetal } \\
\text { spleen }\end{array}$ \\
\hline A6 frontal lobe & C6 uterus & $\begin{array}{l}\text { E6 leuco- } \\
\text { cyte }\end{array}$ & $\begin{array}{l}\text { G6 fetal } \\
\text { thymus }\end{array}$ \\
\hline A7 hippocampus & C7 prostate & $\begin{array}{l}\text { E7 lymph } \\
\text { node }\end{array}$ & G7 fetal lung \\
\hline $\begin{array}{l}\text { A8 medulla } \\
\text { oblongata }\end{array}$ & C8 stomach & $\begin{array}{l}\text { E8 bone } \\
\text { marrow }\end{array}$ & - \\
\hline B1 occipital pole & D1 testis & F1 appendix & x H1 yeast RNA \\
\hline B2 putamen & D2 ovary & F2 lung & $\begin{array}{l}\mathrm{H} 2 \text { yeast } \\
\text { tRNA }\end{array}$ \\
\hline $\begin{array}{l}\text { B3 substantia } \\
\text { nigra }\end{array}$ & D3 pancreas & F3 trachea & $\begin{array}{l}\text { H3 E. coli } \\
\text { rRNA }\end{array}$ \\
\hline B4 temporal lobe & $\begin{array}{l}\text { D4 pituitary } \\
\text { gland }\end{array}$ & F4 placenta & H4 E.coli DNA \\
\hline B5 thalamus & $\begin{array}{l}\text { D5 adrenal } \\
\text { gland }\end{array}$ & & H5 Poly r(A) \\
\hline $\begin{array}{l}\text { B6 subthalamic } \\
\text { nucleus }\end{array}$ & $\begin{array}{l}\text { D6 thyroid } \\
\text { gland }\end{array}$ & & H6 human $\mathrm{C}_{0} \mathrm{t}$ \\
\hline B7 spinal cord & $\begin{array}{l}\text { D7 salivary } \\
\text { gland }\end{array}$ & & $\begin{array}{l}\text { H7 human } \\
\text { DNA }\end{array}$ \\
\hline & D8 mammary & & H8 human \\
\hline & & & \\
\hline
\end{tabular}

\section{Results}

Nephrin $m R N A$ in the human pancreas. Expression of nephrin mRNA was studied in 50 different human tissues with the Human RNA Masterblot. After hybridisation with the human nephrin probe, a clear hybridisation signal was observed only in adult (square E1 in the Masterblot) and fetal kidney (G3) as well as in the pancreas (D3) (Fig.1). The signal was strongest in the fetal kidney. Pancreas and kidney showed equal signal intensity. However, the result should be 


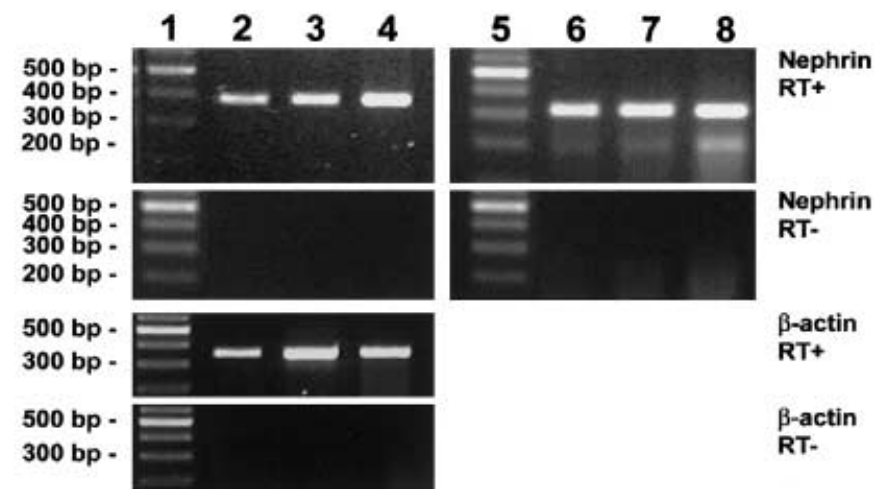

Fig. 2. RT-PCR with nephrin primers. Complementary DNA from human isolated islets of Langerhans (lanes 2 and 6), pancreas (lanes 3 and 7) and kidney cortex (lanes 4 and 8) was amplified with the primer pair 2606-2979 upstream from the transmembrane region (lanes 2-4) or with the primer pair 3094-3402 on either side of transmembrane region (lanes 6-8). Lanes 1 and 5 show the 100 base pair (bp) molecular marker. RT + , reverse transcriptase used in the sample preparation, RT-, the same sample without reverse transcriptase reaction. The lanes also show PCR results with the $\beta$-actin primers and respective RT- reactions

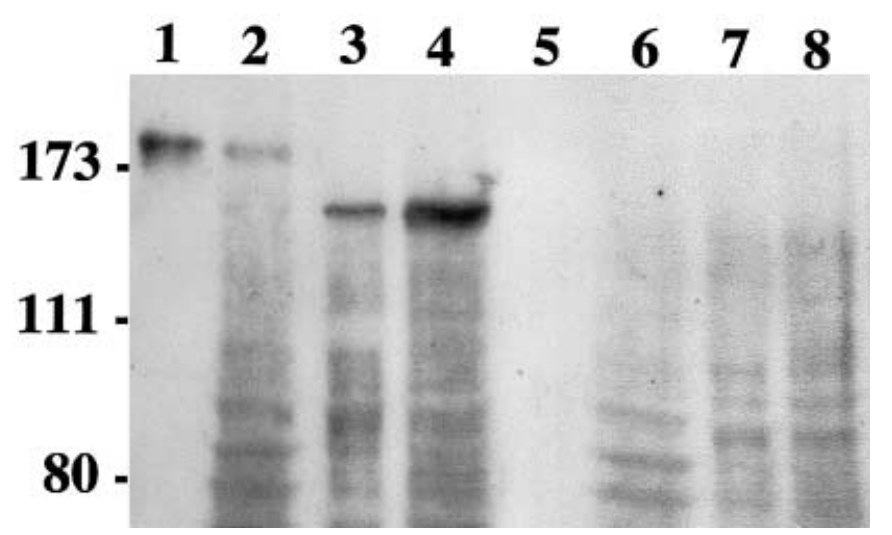

Fig.3. Immunoblot. The lysates: human kidney glomeruli (lane 1 and 5), human kidney cortex (lane 2 and 6), human pancreas (lane 3 and 7) and human islet preparation (lane 4 and 8). Lanes 1-4 were stained with nephrin antibody and lanes 5-8 with antigen preadsorbed nephrin antibody. The figure shown is a representative of seven experiments (the sample combination varied but always included at least one sample from the kidney and one from the pancreas). The blocking of the staining was done twice. The molecular weights of the prestained marker (Gibco BRL, Life Technologies) are the values shown $\cdot 1000$

regarded as qualitative or at the most semi-quantitative because the dot blot is normalised with an average signal of eight housekeeping genes. Therefore the amount of mRNA of each dot is dependent of transcriptional activity of the housekeeping genes used in the normalisation.

With RT-PCR, nephrin and $\alpha$-nephrin mRNA were detected in isolated islets of Langerhans (Fig. 2, lanes 2 and 6), human pancreas (lanes 3 and 7), as well as in human kidney cortex (lanes 4 and 8). With the primer pair 2606-2979 upstream from the putative transmembrane region of human nephrin a single product of an expected size (374 bp) was obtained (lanes 2-4). The other primer pair with the sense primer 3094 upstream and the anti-sense primer 3402 downstream of the exon 24 encoding the transmembrane area showed two bands (lanes 6-8): one approximately $310 \mathrm{bp}$ and another of about $190 \mathrm{bp}$. These sizes correspond precisely to the expected product size of the full-length nephrin and $\alpha$-nephrin, respectively. The clearly dominant form in the pancreas was the full-length nephrin. The absence of the exon 24 (120 bp) in $\alpha$-nephrin was confirmed by sequencing (data not shown). The RT- reactions showed no PCR product thus excluding contamination of DNA. All $\beta$-actin reactions gave the expected PCR product ( $350 \mathrm{bp}$ ).

The nephrin mRNA between bases 1 and 4285 was sequenced from a human pancreatic cDNA library. The sequence was found to be identical in pancreas and kidney.

Pancreatic nephrin localise in the beta cells. On immunoblotting the affinity purified nephrin antibody detected a band at $185000 \mathrm{M}_{\mathrm{r}}$ in human glomerular lysate (lane 1) (Fig. 3). In kidney cortex two specific protein bands were detected (lane 2). The $\mathrm{M}_{\mathrm{r}}$ values of the proteins were 185000 and 165000 . Pancreas and the islets of Langerhans showed only the 165000 $\mathrm{M}_{\mathrm{r}}$ band (lanes 3-4). In the islet preparation the band was stronger than in the pancreas lysate. Preadsorbtion with the antigen peptide completely abolished the immunoreactivity (lanes 5-8) (Fig. 3).

The nephrin (E1) antibody stained the islets of Langerhans in frozen sections of human pancreas (Fig.4A). Nephrin-positive cells were localised centrally in the islets of Langerhans. The specificity of nephrin immunoreactivity was confirmed in a blocking experiment: the staining of nephrin antibody was abolished by preincubation of the antibody with the antigen peptide (Fig.4B). In dual immunofluorescence, nephrin was detected with TRITC conjugated antibody and insulin, glucagon, somatostatin and cytokeratin 19 with FITC conjugated antibody. Nephrin and insulin exhibited clear co-localisation: insulin positive cells also showed nephrin positivity and insulin negative areas lacked nephrin staining (Fig. 4C-E). However, the staining intensity of the beta cells varied. In some beta cells both signals were strong while others showed fainter insulin staining but more intense nephrin staining, and vice versa. Neither glucagon (Fig. 4F-H) nor somatostatin (Fig. 4I-K) positive cells co-localised with the nephrin positive cells further indicating beta-cell specificity of nephrin. The cytokeratin 19-positive ductal cells showed no colocalisation with nephrin (Fig. 4L-N). 


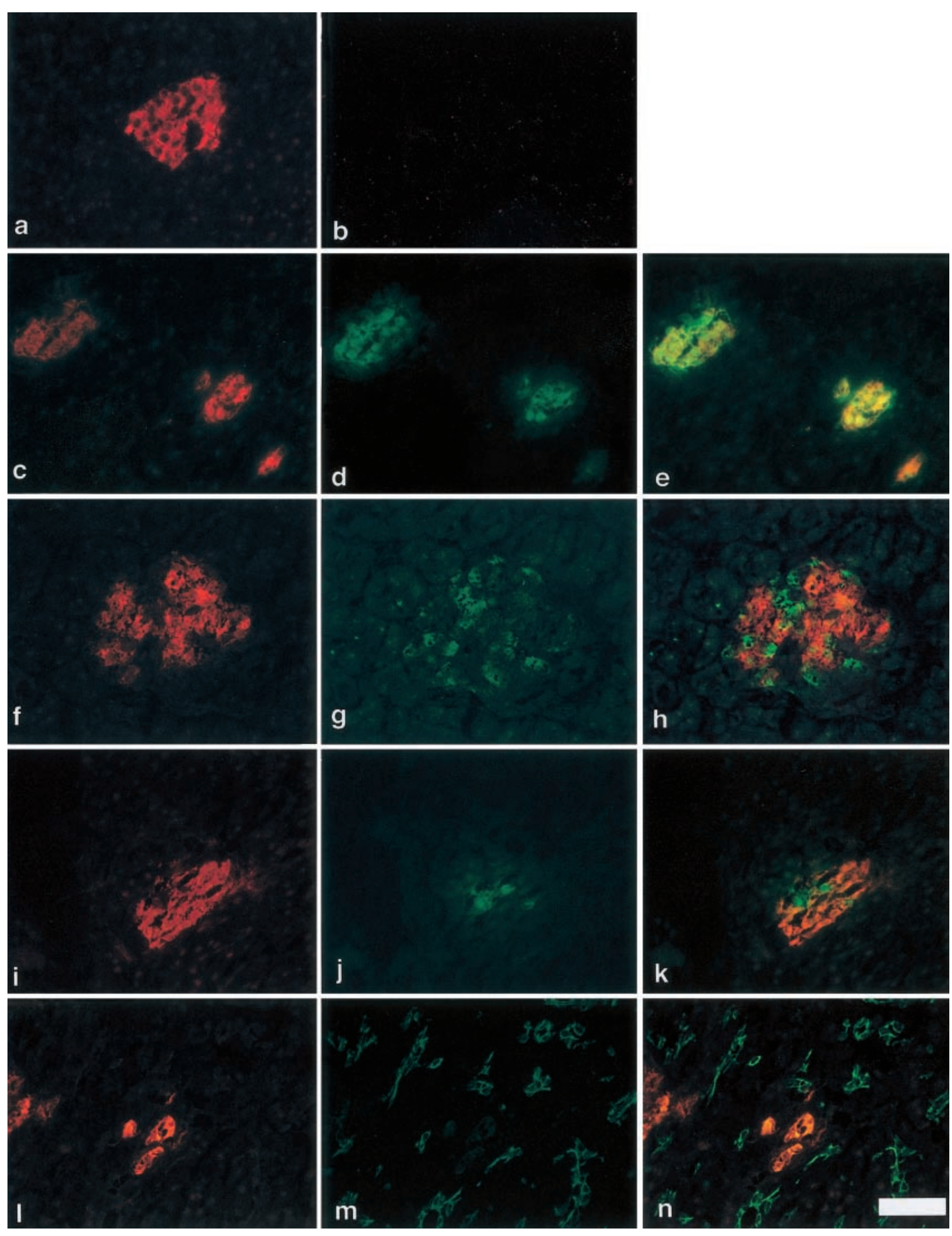




\section{Discussion}

In this study we showed a novel limited expression site of nephrin in the human pancreas. No nephrin expression was detected in extrarenal or extrapancreatic sites among the fifty different tissues as screened with a human tissue RNA dot blot. Identification of the nephrin sequence from a human pancreas cDNA library and the specific RT-PCR verified the expression of nephrin in pancreas. Within the pancreas nephrin appears very specifically in the insulin-producing beta cells in the islets of Langerhans. This is supported by the following observations: First, nephrin mRNA was detected by RT-PCR in RNA prepared from isolated human islets of Langerhans. Second, immunoblotting with intracellular nephrin antibody showed a stronger signal in the islet preparation than in human pancreas lysate. Third, immunofluorescence using nephrin antibody identified the centrally located islet beta cells and excluded other endocrine cell types. Finally, the immunoreactivity of the nephrin antibodies was effectively blocked by appropriate antigenic peptide on immunoblotting and in immunofluorescence.

We also found the truncated $\alpha$-nephrin mRNA variant in the pancreas. Like in human and rat kidney this splice variant lacked the sequence encoding the transmembrane region [7-8]. In humans the spliced portion is $120 \mathrm{bp}$ in length, and corresponds exactly to the size of exon 24 [6]. In the immunoglobulin superfamily alternative splicing has shown to be a way to produce secreted isoforms [17]. The soluble nephrin could thus be involved in the regulation of the biological functions of nephrin. Such a mechanism is proposed for some other transmembrane proteins like the interleukin- 6 receptor [18] and $\operatorname{CD} 3 \gamma$ chain of pre-T-cell antigen receptor [19].

In addition to alternative splicing, adhesion properties of a protein can be modulated by glycosylation [20]. The $M_{r}$ of nephrin predicted by its amino acid sequence is 135000 , but the apparent $\mathrm{M}_{\mathrm{r}}$ of glomerular nephrin is 185000 [5, 7-9]. The observed difference has been explained by post-translational modifications because nephrin has 10 potential N-glycosylation sites [5-6]. Consistent with this suggestion deglycosylation has been shown to reduce the molec-

Fig. 4. Immunofluorescence. Frozen sections of human pancreas were stained with nephrin antibody (A) and nephrin antibody preadsorbed with antigen $(\mathbf{B})$. The figures $\mathbf{A}$ and $\mathbf{B}$ are representatives of ten similar experiments. The dual staining of nephrin (red) (C) and insulin (green) (D) as well as an overlay of them $(\mathbf{E})$. The respective dual staining for nephrin and glucagon $(\mathbf{F}-\mathbf{H})$, for nephrin and somatostatin $(\mathbf{I}-\mathbf{K})$ and nephrin and cytokeratin $19(\mathbf{L}-\mathbf{N})$. The figures $\mathbf{C}-\mathbf{I}$ are representatives of two similar experiments. Bar: $45 \mu \mathrm{m}$ ular mass of glomerular nephrin to approximately $135000 \mathrm{M}_{\mathrm{r}}$ [9]. The $\mathrm{M}_{\mathrm{r}}$ of pancreatic nephrin as detected with intracellular antibody was $165000 \mathrm{M}_{\mathrm{r}}$ The $M_{r}$ size difference between 185000 and 165000 can be explained with a different post-transcriptional modification of nephrin, for instance with a minor, tissue specific glycosylation. This is supported by the finding that the intracellular antibody detects both 185000 and $165000 \mathrm{M}_{\mathrm{r}}$ bands whereas a monoclonal extracellular domain antibody of nephrin only shows the lower $165000 \mathrm{M}_{\mathrm{r}}$ band (data not shown).

Consisting of eight extracellular immunoglobulinlike domains, a fibronectin type III domain, a transmembrane region and eight tyrosines in the intracellular part, nephrin is a putative member of the immunoglobulin superfamily [5-6]. The other members of the superfamily have a wide variety of functions in cell adhesion, signalling and migration, typically interacting with each other in a homophilic or heterophilic manner in cell-to-cell or cell-to-matrix contacts [20]. Due to structural homologies it has been proposed that glomerular nephrin is involved in homophilic cell-to-cell interactions and forming the structural-functional basis of the interpodocyte slit membrane [5, 21-22]. The identification of mutations in the NPHS1 gene responsible for the proteinuria in $\mathrm{CNF}$ as well as the evidence of down regulation of nephrin in other human nephrotic syndromes [11] and in experimental rat models of nephrosis [12] support the proposed role of nephrin as an essential component of the slit membrane maintaining the glomerular filtration barrier [21-22]. At present, it is too early to propose a similar precise role for nephrin in pancreatic islet cells. There is no data available on the beta-cell function of patients with CNF. Extensive proteinuria, early nephrectomy and the accompanied medical problems dominate the clinical status of the patients. After kidney transplantation patients undergo immunosupressive therapy which has multiple metabolic effects. Without detailed studies it is difficult to assess whether NPHS1 mutations causing CNF also affect beta cell function. Pancreatic nephrin, like its glomerular counterpart is likely to be involved in cell junctions and/or in signal transduction as suggested by the eight intracellular tyrosines. Neither the ligands binding to the extracellular part of nephrin nor the signalling pathway has been shown. So far, only CD2AP (CD2-associated protein) has been found to interact with nephrin [23]. The regulation of nephrin remains to be studied both in the kidney and in the pancreas.

In conclusion, nephrin mRNA and protein has now been described in two highly specialised cell types in the body: kidney podocytes and beta cells. As little is still known of the shared epitopes in kidney and pancreas, nephrin becomes an interesting molecule for further studies concerning the pathogenesis of diabetes and diabetic nephropathy. 
Acknowledgements. This study was supported by the Helsinki University Hospital, the Päivikki and Sakari Sohlberg Foundation, the Finnish Foundation of Diabetes Research and the Sigrid Juselius Foundation. T. Otonkoski is the recipient of a Juvenile Diabetes Foundation International Career Development Award. We are also indebted to L. Pirinen, E. Häyri and R. Majuri for their excellent practical assistance. In addition, we thank E. Åström (M. Sci) and J. Ustinov (M. Sci) for their valuable help.

\section{References}

1. Rapola J (1987) Congenital nephrotic syndrome. Pediatr Nephrol 1: 441-446

2. Holmberg C, Antikainen M, Rönnholm K, Ala-Houhala M, Jalanko H (1995) Management of congenital nephrotic syndrome of the Finnish type. Pediatr Nephrol 9: 87-93

3. Kestila M, Mannikko M, Holmberg C et al. (1994) Congenital nephrotic syndrome of the Finnish type maps to the long arm of chromosome 19. Am J Hum Genet 54: 757-764

4. Männikkö M, Kestila M, Holmberg C et al. (1995) Fine mapping and haplotype analysis of the locus for congenital nephrotic syndrome on chromosome 19q13.1. Am J Hum Genet 57: 1377-1383

5. Kestilä M, Lenkkeri U, Männikkö M et al. (1998) Positionally cloned gene for a novel glomerular protein - nephrin is mutated in congenital nephrotic syndrome. Mol Cell 1: 575-582

6. Lenkkeri U, Männikkö M, McCready et al. (1999) Structure of the gene for congenital nephrotic syndrome of the Finnish type (NPHS1) and characterization of mutations. Am J Hum Genet 64: 51-61

7. Holthöfer H, Ahola H, Solin M-L et al. (1999) Nephrin localizes at the podocyte filtration slit area and is characteristically spliced in the human kidney. Am J Pathol 155: 1681-1687

8. Ahola H, Wang SX, Luimula P, Solin M-L, Holzman LB, Holthofer H (1999) Cloning and expression of the rat nephrin homolog. Am J Pathol 155: 907-913

9. Holzman LB, St John PL, Kovari IA, Verma R, Holthofer H, Abrahamsom DR (1999) Nephrin localizes to the slit pore of the glomerular epithelial cell. Kidney Int 56: 1481-1491

10. Ruotsalainen V, Ljungberg P, Wartiovaara J (1999) Nephrin is specifically located at the slit diaphragm of glomerular podocytes. Proc Natl Acad Sci USA 96: 7962-7967
11. Furness PN, Hall LL, Shaw JA, Pringle JH (1999) Glomerular expression of nephrin is decreased in acquired human nephrotic syndrome. Nephrol Dial Transplant 14: 1234-1237

12. Luimula P, Ahola H, Wang SX et al. (2000) Nephrin in experimental glomerular disease. Kidney Int 58: 1461-1468

13. Luimula $\mathrm{P}$, Aaltonen $\mathrm{P}$, Ahola $\mathrm{H}$, Palmen $\mathrm{T}$, Holthofer $\mathrm{H}$ (2000) Alternatively spliced nephrin in experimental glomerular disease of the rat. Pediatr Res 48: 759-762

14. Putaala H, Soininen R, Kilpeläinen $\mathrm{P}$, Wartiovaara J, Tryggvason K (2001) The murine nephrin gene is specifically expressed in kidney, brain and pancreas. Hum Mol Genet 10: 1-8

15. Frangioni JV, Neel BG (1993) Solubilization and purification of enzymatically active glutathione S-transferase (pGEX) fusion proteins. Anal Biochem 210: 179-187

16. Kerjaschki D, Farguhar MG (1982) Immunocytochemical localization of the Heymann nephritis antigen (gp 330) in glomerular epithelial cells of normal Lewis rats. J Exp Med 157: 667-686

17. Gower HJ, Barton CH, Elsom VL et al. (1988) Alternative splicing generates a secreted form of N-CAM in muscle and brain. Cell 55: 955-964

18. Säily M, Koistinen P, Pulkki K, Zheng A, Savolainen E-R (1998) Acute myoblastic leukaemia cells produce soluble interleukin 6 receptor by mechanism of alternative splicing. Cytokine 10: 860-867

19. Takase K, Okazaki Y, Wakizaka K, Shevchenko A, Mann M, Saito T (1998) Molecular cloning of pTAC12 an alternative splicing product of the CD3 $\gamma$ chain as a component of the pre-T cell antigen receptor complex. J Biol Chem 273: 30675-30679

20. Brümmendorf T, Rathjen FG (1994) The immunoglobulin superfamily. In: Sheterline P, Humphries M, Latchman D, Downes P (eds) Protein Profile. Vol 1. Academic Press Limited, London, pp 951-1058

21. Tryggvason K (1999) Unraveling the mechanisms of glomerular ultrafiltration: nephrin, a key component of the slit diaphragm. J Am Soc Nephrol 10: 2440-2445

22. Tryggvason K, Ruotsalainen V, Wartiovaara J (1999) Discovery of the congenital nephrotic syndrome gene discloses the structure of the mysterious molecular sieve of the kidney. Int J Dev Biol 43: 445-451

23. Shih NY, Li J, Karpitskii V et al. (1999) Congenital nephrotic syndrome in mice lacking $\mathrm{CD} 2$-associated protein. Science 286: 312-315 